\title{
Matthew Rohrer
}

\section{Ron Padgett's New and Selected Poems}

It would be difficult to open Ron Padgett's New and Selected Poems without noticing right away that it's a very different book from other New and Selected Poems you've seen. It's not divided into sections chronologically; the poems aren't labeled or in any recognizable order; new poems appear between old favorites; poems you don't recognize could be new or from a book you've never seen; and on its most basic level, it's short. It's only 120 pages. But those pages contain the poems of one of America's foremost poets of the imagination.

Padgett's New and Selected Poems spans thirty years-1963 to 1993in which he was writing some of the most exciting and varied poetry available. This new book, though it serves as a collection of his old work, reads like his many earlier books-the playful language, the staggering images, the twisted collage-like logic, the short lyrics are all there. But "the thought of arranging them chronologically, or by book, just seemed very boring to me," he said when I had the pleasure of buying him a chicken sandwich at the Chat-n-Chew in New York. "I wasn't even interested in figuring it out, you know? And I wanted to make a new book, basically, and not just a compilation of old stuff with some new things in it. And I was hoping that by rearranging the work so that it wasn't in chronological order, that it would actually change the feel of some of the old poems." And it does. Padgett's New and Selected Poems is an exciting new book. People unfamiliar with his poetry will be dazzled by it, and his fans will be amazed at the new lives of the old poems.

Ron Padgett has always been a pioneer of a certain movement, sometimes called avant-garde, the Tulsa School, insane, surreal, brilliantdepending on who you're talking to. But always original. And though

David R. Godine, 1996. 
he's remained far from the mainstream, he was by no means an unschooled outsider. He was a Fulbright scholar. He went to Columbia University. In the early 1960s when he first moved to New York from Tulsa, Oklahoma, he read everything he could get his hands on, and naturally kept up with the established writers of the time. He said he remembers liking a few of Lowell's poems, even some of Berryman's "Dream Songs," "but my heart," he said, "was with Frank O'Hara and James Schuyler, Kenneth Koch and John Ashbery ... the so-called New York School." But Padgett's poetry was very different from the New York School's. Partly joking, he and fellow Tulsans Ted Berrigan, Dick Gallup and Joe Brainard, who all moved to New York in the early 1960 s, founded the new generation of New York avant-garde poetsthe Tulsa School. In the 1960s Padgett got involved with the writers who would later make up the St. Mark's Poetry Project, and at the end of the 70s became the director of the Poetry Project for several years. He had been teaching art to kids for awhile, through the Teachers and Writers Collaborative, and eventually took a job as their Publications Director, which he still does today.

But how does a writer persist with sparse acclaim, and persist in being innovative and free on the page for thirty years of relative obscurity? Is that in fact why his writing remains fresh, the lack of scrutiny? "I've been really lucky," he concludes, "incredibly lucky. I married the right person; we've been together for a long time. I was lucky to go to a good school, and lucky to find some good teachers there. I live in one of the most affluent and comfortable countries on the planet. I mean, I could have been born in one of those horrible sad countries where you grow up dead. I've been relatively healthy my whole life. I really can't complain about not being famous. I just feel lucky to have lived the life I have-not that I haven't had to work-I haven't yawned my way through it, but I've been, I've been blessed, really."

But he hasn't simply been blessed; he's also been writing beautifully strange poetry, and collaborating with other writers like Berrigan and Tom Veitch, and with artists like Jim Dine, George Schneeman and his first grade friend and fellow Tulsa School member Joe Brainard. He's published many of these collaborations, and several brilliant little books of poetry. Padgett attributes much of his writing style to his early fascination with collaborations. "Ted (Berrigan) and I did our first col- 
laboration in 1959. We didn't even know anyone had ever done that before. Then we did a bunch more in New York in the 60s. But it's hard for me to go back to the time before I did collaborate with anybody, because once I did collaborate with people, it changed the way I wrote when I was alone. It got me out of having just one voice in my head."

This is probably the most distinguishing feature of Padgett's poetryas a whole and individually the change in tone and voice is often staggering, satirical and always very aware of itself. There is no pretense that the poems are going to change the world, or end police brutality-they're against that of course, but they never lose sight of their reality: they're poems. And it's refreshing and important for a young writer to realize this. His teachers may be telling him writing isn't True Writing unless it's in the service of this or that agenda. His contemporaries are almost certainly showing him methodical, unenlightened introspection, such as makes up most of late 20th Century poetry. Reading Padgett's poetry can free one of much of that. I, for one, learned that I could simply write, without the essayist's burden of having to diagnose and solve problems-I could just write because it confounded me and I enjoyed it. And because his poetry is so immediate to what was present with him when he wrote it, when I read it, it feels like it's happening again. It feels like he's driving me through a strange city that only he knows his way around, but I don't worry that it's dangerous because he's always cracking jokes with the lurking shadows. (I'm imagining us in a ' 72 Fleetwood with Oklahoma plates). While driving, he recasts everything he sees in his mind, as in "Poem," for instance, in which the voice and language shift from banal statement to wistful reminiscence to beautiful absurdity.

Poem

When I am dead and gone they will say of me, "We never could figure out what he was talking about, but it was clear that he understood very well that modernism is a branch 
that was cut off decades ago."

Guess who said that.

Mutt and Jeff

who used to look so good in the comics.

I especially liked their mustaches.

And the sense in it

that God is watching

from some untelevised height,

and sometimes

throws himself on the ground.

There is a tremendous impact,

for the molecules of God

are just tremendous.

"Poem" is important in several ways, which are basically the same reasons most of Padgett's poems are great. First, it's entertaining, not prescriptive. In fact I find it downright funny, but that's a preference I have-I find shifts in tone and absurd juxtapositions a riot. "Poem" is also able to contain several attitudes at the same time, and this seems so much more human and honest than a poem that proposes a problem and then arrives at the conclusion. Or a poem about women (or men) as the only true heirs to the natural, spiritual forces. On one level this poem is interested in the actual discourse-the words used, and how they sound. They sound funny put together the way they are because of the pseudo-academic tone in the beginning, the straightforward reminiscing in the middle, and the heightened surreal language used to describe God's molecules at the end. The poem also seems better to me than a straight account of a broken heart, or a half-remembered childhood atrocity, because it never tries to cover up the fact that it's not an emotion or an event, but rather, it's a poem he wrote later, after thinking about it for awhile, and letting other things creep into his thoughts. Or there are his ecstatic odes-one to chocolate milk and one to Woody Woodpecker:

To Woody Woodpecker

I love you, Woody, when you peck 
on the head

of a bad person

and laugh and fly

away real fast,

speed lines

in the air

and clouds of invisible

dust dissipating,

I love the way

you last only seven minutes

with Woody Woodpecker,

seven minutes of pure bliss.

Or he's chanting his list poems, like "Nothing in That Drawer"-a sonnet, in a sense: fourteen lines, each of which says "Nothing in that drawer." And while driving through this strange place, he recites his poems about writing poems, like "Joe Brainard's Painting 'Bingo'” which begins,

I suffer when I sit next to Joe Brainard's painting "bingo.”

I could have made that line a whole stanza:
I suffer
When I sit
Next to Joe
Brainard's painting
"Bingo"

This poem goes on to discuss, among other things, the possible arrangements of these words, what it might be like to have hemorrhoids, and the fact that he didn't originally say the first line in the first place. It ends,

My wife said it

In response to something I had said

About another painting of his

She had misunderstood what I had said. 
What's the poem about? A misunderstanding? Partly, but it's also about how much Ron Padgett enjoys writing, and how at its most basic level, a poem is a product of the imagination, and is always in some way about the imagination. William Carlos Williams, who called poems "small machines made of words" and was one of our first spokesmen for the imagination, would have agreed with this. And I think he would have loved Padgett, who said "My job is just to make these little things. I just sit down with them and make them-and something I don't hear very often is writers say that it's fun, writing, but it is, you know? It's fun making these little machines and making them turn out like you wanted-well, never like you wanted but in a way you like."

Ron Padgett's poems always seem fresh, no matter how many times I reread them, because they're fossils of the experience of writing the poem. His poetry shows that good writing can be nearly indistinguishable from living, and that's what should make Padgett's work of interest to anyone who spends time thinking about the relationship between language and life. The poems are a record of what was present with him as he was writing-thoughts, sounds, people passing on the street-filtered through the act of writing. Many of his poems begin as meditations on something banal, only to end somewhere totally unexpected, and tenuously connected. If you've taken a course in modern American poetry, someone has told you that Wallace Stevens was the poet of the imagination. That he was a quiet, dull man who lived out his life in his poems. But Ron Padgett is the poet of the act of the imagination. His poems celebrate the mind and the things it does with what it's given. They celebrate playing and the process of writing-the thinking behind the poem is often the whole poem, as in "Joe Brainard's Painting 'Bingo." While so much contemporary poetry declaws ideas, making interesting issues pedantic, Ron Padgett's work shines. When it's serious it's not maudlin; he doesn't overplay his intellect, but instead uses it to get into the more exciting work of collecting poems from his imagination:

Where I may go at will

And sit down and tap

My forehead against the sunset

Where he takes off the uniform

And we see he is God 
God get out of here

And he runs off chirping and chuckling into his hand

And that is a wonderful thing

... a tuba that is a meadowful of bluebells

is a wonderful thing

and that is what I want to do

Tell you wonderful things 